\title{
Social Changes and Better Health Conditions of the Portuguese Population 1974-2000
}

\section{Teresa Rodrigues Veiga, Maria João Guardado Moreira, and Ana Alexandre Fernandes}

The main purpose of this chapter is to illustrate the most significant changes in mortality rates and health status and their impact on Portuguese society.

1 For practical purposes, we have taken into consideration two major problems, and we have approached them following different methodologies. Firstly we detect changes in Portuguese mortality rates using some demographic indicators and correlate this to the broader socio-economic changes that have occurred. Secondly we focus on the role of the National Health Care System as well as alternative institutional support at all levels.

The methodological approach followed varies according to the available statistical data on health and death. Official statistical data on population movements became of scientific interest at the beginning of the modern era, by the end of the 19th century. The records on population movements became reliable by the second half of the 19th century, although it was not until the late 1880s that the publication of demographic statistics began. This data provides information on basic mortality rates, fertility rates and migratory movements during the last 150 years. After 1864, a reliable general census of the population is made. Nevertheless, major changes in the global quality of data will not be introduced until the 1930s.

\section{General Demographic Trends}

During the $19^{\text {th }}$ and $20^{\text {th }}$ centuries, the processes of urban growth, industrialization and migration were the main explanatory factors of national demographic movements. After 1974, migratory movements within the country became more relevant, and population density increased in the coast. In recent years, the importance of such movements has been partly replaced by immigration. 
Figure 1. Number of births and deaths during the $20^{\text {th }}$ century.

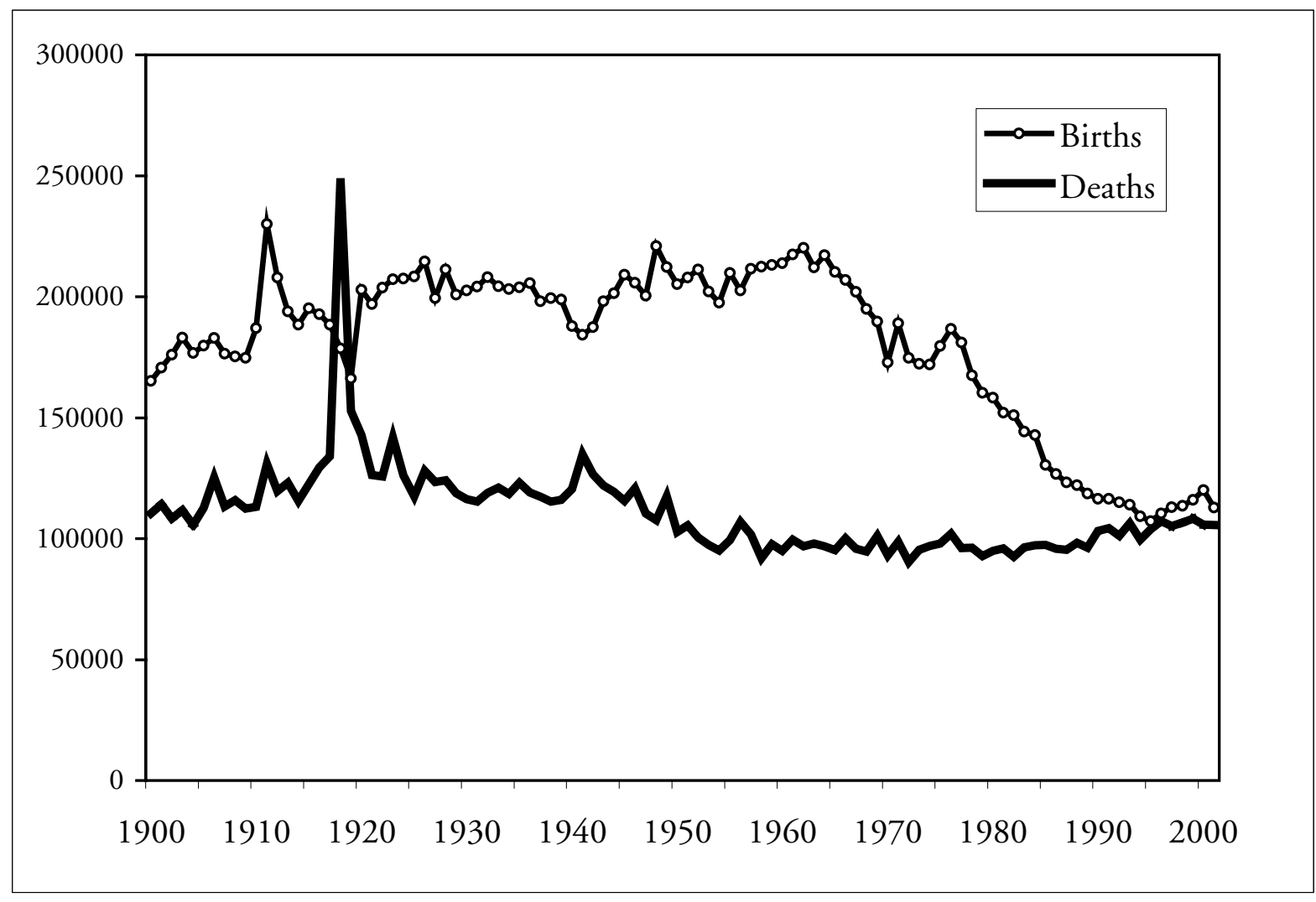

Source: Estatísticas Demográficas, INE, Lisboa, 1910-2001.

Today, Portuguese society presents an almost inexistent level of demographic growth, a high rate of life expectancy, low levels of fertility rates and an increasingly elderly population. All these demographic trends converge and create a model with slight regional variations.

In the diachronic axis, Portugal has presented moderate growth rates for the last two centuries, with variations and asymmetries between the mainland and the islands - Azores and Madeira -, the northern and southern parts of the country, the coast and the countryside. However, it is possible to distinguish clear-cut phases and sub-periods, which differ with regards to total annual average growth rates and variation rates (table 1 in appendix).

In the contemporary era, industrialization has had an obvious effect on migration and regional differences within the country. At the same time, political stability and the improvement of life conditions helped to change mortality rates, compensating for the negative tendency of the migratory flow and enhancing the general growth of the population. In 1918, the "Spanish flu" brought such tendency to a halt, but after that period population experienced a new growth (figure 1). An analysis of the total annual growth rates and of net migratory rates from 1900 up to 2001 (table 2 in appendix) shows that in the last 100 years the population increase in Portugal has always depended on the intensity of the migratory flow, and more in particular 
from the third quarter of the $19^{\text {th }}$ century onwards. ${ }^{1}$ Migration within the country increased after the 1870s, reinforcing a new pattern vis-à-vis fertility and mortality ratios. The crack of 1929 and the Second World War slowed emigration rates. During that period, war refugees influenced the increase of population rates. In the 1940s emigration started out again and, as a consequence, population growth slowed down and actually decreased between 1960 and 1974. However, after the $25^{\text {th }}$ of April, Portuguese and African citizens from previous colonies provoked a population growth of $7 \%$. In the last thirty years, it is necessary to consider stability as the keyword to describe demographic reality. ${ }^{3}$

Between 1855 and 1930, more than 2 million people left the country and 2 more millions followed them between 1930 and 1970, 40\% of them during the 1960s. After 1975, emigration rates dropped. Between 1974 and 1976, almost half million Portuguese citizens returned to Portugal from former African colonies. Nevertheless, in the 1980s, emigration increased again, with an annual flow of 26 thousand persons per year, but with new destinations and most of them on a temporary basis. ${ }^{4}$ Immigration patterns change too. European immigration has increased in the last five years. ${ }^{5}$ One third of the immigrants come from the EU and other European countries (31.9\%); some others come from Africa (45.6\%), mainly from Cabo Verde (14.6\%). Brazilians represent a $14.6 \%$ of the total.

According to the last two censuses of 1991 and 2001, Portugal population shows an average annual increase of $0.45 \%$, significantly higher than that of the previous decade, almost entirely due to immigration. Yet, this average value does not reflect the whole story, as some regions, since the mid-80s, show significant reductions in population figures. Population has grown old. At the beginning of the $20^{\text {th }}$ century, the ratio of old and young people was of one to six. By the middle of the century the ratio was one to four, but from the 1960s onwards, swift changes have taken place. The last census counted 1.7 million people over 65, which represents an increase of $44 \%$ vis-à-vis 1981 . In the same period, young population decreased by $37 \% .{ }^{6}$ Today, only $16.0 \%$ of the population is below $15,16.4 \%$ is over 65 . Portugal

1 Maria Ioannis Baganha, "A emigração atlântica e as migraçôes internas em Portugal”, in Los 98 Ibericos y el mar, IV, (Lisboa, 1998), 215-228.

2 On this subject see Manuel Nazareth, Portugal. Os próximos 20 anos, III - Unidade e diversidade da demografia portuguesa no final do século XX, (Lisboa, 1988).

3 Teresa Rodrigues, "A população portuguesa no século XX - Permanências e mudanças”, Ler História, 53, (Lisboa, 2003).

4 In the last five years of the 20th century, temporary emigration has always represented more than half of the total of legal exits (maximum value of $86 \%$ in 1999). In 2000 and 2001, 21,333 and 20,589 declarations of temporary exit represented a $78 \%$ and a $72 \%$, respectively.

5 In 2001, 27.5\% of all the European immigrants came from other EU countries (the United Kingdom, Spain and Germany being the most representative ones).

6 Data taken from the census of 2001 show that Portugal has 1,656,602 young inhabitants (from 0 to 14 years) and 1,693,493 elderly inhabitants (65+ years old). 36,891 young 
is one of the five countries of the European Union with fewer younger than elderly people.

In the coast, population is younger, but in the south and in the countryside population is older. As migrants are young, their settlement implies the rejuvenation of the regions they move to and the ageing of those where they came from. This trend has benefited the Portuguese coast, whose population increased during the second half of the $20^{\text {th }}$ century, at the expense of the countryside. Regions with a higher percentage of elderly inhabitants are in the south and in the interior of the country. There are, however, local variations that must be registered, since villages and small towns are more affected than cities, and isolated places with bad accessibility are also noticeably affected. As migrants are mostly individuals in their fertile age, their movement from one place to the other has also negative and positive consequences on fertility rates in the places they leave and they arrive to, respectively. Still, ever since the mid $-20^{\text {th }}$ century, and mostly during the last thirty years, the decline of the average number of children per woman has led to the narrowing of the base of the population pyramid of Portuguese population age rate.

Migration towards new economic, more attractive areas has led to the abandonment of the countryside, ${ }^{8}$ to the creation and, sometimes, to the chaotic growth of suburbs around big cities and to the formation of metropolitan areas.' A study about the recent evolution of the Portuguese urban system shows that in almost all regions the nucleus with urban functions has augmented in size, or at least, has experienced lower demographic losses vis-à-vis towns of smaller dimensions. ${ }^{10}$

people less. All regions have contributed to this inferiority, except the regions of the north and the islands. In the Alentejo, the proportion is of 174 old persons to 100 young ones; in the central region of the country of 131; in the Algarve of 128; and in Lisbon and Vale do Tejo of 110. In the north this ratio is of 80 elderly people to 100 young people. The Autonomous Regions of Madeira and the Azores have the youngest population in the country, with only 72 and 61 aged people to 100 young people, respectively.

7 Cf Maria João Guardado Moreira, A Dinâmica demográfica na região do INTERREG Ibérico no Final do Século XX, FCSH-UNL (Lisboa, 2001); Maria José Carrilho, "Evolução Demográfica no período intercensitário 1991-2001”, Seminário Censos 2001 - Resultados Definitivos, INE, (Lisboa, 2002).

8 Several studies indicate that $80 \%$ of migrants moved from rural areas to urban centres. Only 29\% moved from one urban centre to the other (Teresa Rodrigues and Maria Luís Rocha Pinto, "Migrações internas", Dicionário de História do Estado Novo, II, Círculo de Leitores, ( Lisboa, 1996), 561-565).

9 Teresa Rodrigues and Luís Baptista, "Population and Urban Density: Lisbon in the 19th and 20th centuries", Urban dominance and labour market differentiation of a European capital city. Lisbon, 1890-1990, Kluwer Academic Publishers, (London, 1996), 75-122.

10 The methodological presupposition based on Portuguese reality is that all settlements with two thousand or more residents have infrastructures that allow us to consider them urban 
Coastal cities and villages have continued to attract people from the interior, but the great beneficiaries have been the surrounding areas of Lisbon and Porto. In the case of Porto, the regions of Braga and Aveiro are to be mentioned, while in the case of Lisbon, it is Setubal that must be referred to. ${ }^{11}$ These are, together with Faro, the preferred settlement by immigrants, and they present the highest demographic dynamics. Today more than three quarters of the country show negative natural rates. In fact, during the 1990 s, $82 \%$ of Portuguese population total growth is due to positive migratory rates.

\section{Fertility Changes}

The first phase of demographic transition extended up to 1925 and it was characterised by a decrease in mortality, while fertility rates continued to be high. This would lead to high rates of population growth between the late $19^{\text {th }}$ century and the first quarter of the $20^{\text {th }}$ century, if it were not for the unfavourable migratory balance. However, after 1930 the situation was much the reverse with a slight decrease in birth rates. Between 1940 and 1960, the average Portuguese fertility rate remained stable. It was only in the 1970s that the fecundity of Portuguese women decreased by $25 \%$ from 3 to 2.2 children per woman. In 1982, the country ceased to guarantee generational continuity. Still, in the last five years the fertility rate has stabilised around 1.5, with a slight rising tendency.

The traditional family model based on asymmetric conjugal roles followed its course until the late 1960s, as guarantee of social harmony zealously promoted by the political and religious institutions of Salazar's regime (the so-called "Estado Novo"). Portugal began to enjoy new social and political conditions from the revolution of 1974 onwards, and this seems to have had a strong influence on parental and familiar behaviour. The cohabitation rate (mixed couples) increased, as well as divorce frequency and the amount of one-parent families, which are both signs of the deep-rooted modifications that characterize Portugal nowadays, with slight regional differences. ${ }^{12}$

Portugal has traditionally low proportions of newborns outside marriage, and its decline is steady between 1930 and 1970. At that time, it represented a 7.2\% of the total birth rate, a $9.5 \%$ in 1981 and a $15.6 \%$ in 1991 , and it has reached $23.8 \%$

centres. (Teresa Rodrigues and Maria Luís Rocha Pinto, “1981-1991: as tendências recentes da evolução populacional portuguesa”, História, 26, (Lisboa, 1996), 44-53).

11 Luís Baptista, "Dominação demográfica no contexto do século XX português: Lisboa, a capital”, Sociologia - problemas e práticas, 15, (Lisboa, 1994), 53-77.

12 In the past, divorces and one-parent families were more usual in the south and in urban areas. (Ana Fernandes, Velhice e Sociedade, Celta Editora, (Lisboa, 1997)). 
presently. The average age of women who give birth for the first time has increased since the beginning of the $1980 \mathrm{~s}^{13}$ At the same time, the proportion of people living alone has risen to $45 \%$, particularly in the case of people over $65 .{ }^{14}$ Families with children under 15 represented $46.9 \%$ in $1981,39.9 \%$ in 1991 and only $29.9 \%$ in 2001. All these changes have led to a decrease of the average family size. ${ }^{15}$

\section{The Mortality Model and the Epidemic Transition}

By the end of the 19th century, Portugal seemed to be facing a slow demographic transition. In spite of all the sudden transformations occurred during that century in the economic and social fields, this variable remained stable with regards to annual volumes. Within the country, the battle against death took place in two fronts chronologically separated in time. At first, it was based on progress carried out at a preventive level. Health authorities managed to halt dissemination of various epidemics at bay by several means, of which isolation barriers are a case in point. ${ }^{16}$ "At the beginning of the $19^{\text {th }}$ century, epidemics became a real state affair." ${ }^{17}$ In fact, it was the central government that played a central role during the several crises that took place throughout the country. In this regard, Portugal took advantage over neighbouring Spain. ${ }^{18}$ Hygienists' campaigns came in the second place, as well as the vaccination campaigns that followed Jenner and Pasteur's discoveries. These were to produce specific positive results for the improvement of general health conditions, though this was not yet clear at the turn to the $20^{\text {th }}$ century. Several factors interfered and caused localised alterations in these indicators: differences between life in rural and in urban areas, greater female participation in the labour market, percentages of young or elderly people in some parts of the country, political and/or economic instability. ${ }^{19}$

13 From 23.6 years in 1981 to 26.8 years in 2001(EUROSTAT (2000); Indicadores Estatisticos Gerais (www.ine.pt)).

14 From $10.8 \%$ in 1960 to $17.3 \%$ in 2001 . According to the 1991 census, they represent $55.5 \%$. Ten years later, the number rose to $50,8 \%$.

15 They were 69,7\% in 1981, 60,8\% in 1991 and 54,3\% in 2001.

16 Teresa Rodrigues and Piedade Braga Santos, "Poder central e poder local, um caso de conflito", Ler História, 34, (Lisboa, 1998).

17 Jorge Crespo, A Economia do Corpo em Portugal nos finais do Antigo Regime, I, UTL, (Lisboa, 1984), 192.

18 See Teresa Rodrigues and Piedade Braga Santos"Poder central e poder local, um caso de conflito", Ler História, 34, (Lisboa, 1998), 71-77.

19 Teresa Rodrigues, Crises de Mortalidade em Lisboa. Séculos XVI e XVII, Livros Horizonte, (Lisboa, 1991), $76 \mathrm{ff.}$ 
The tragedy of death became dramatically noticeable in places with higher population densities, leading to the common idea that mortality rates were higher in urban centres, and mainly in big cities, which was not always true. On the one hand, in some of those cases it was foreigners who died in cities. The existence of hospital institutions, charities, asylums and hospices attracted the poorer and sicker, some of which used to live outside the city. On the other hand, as cities were the abode of important and public figures, there was a link between social notability and the importance of death when it happened during a period of high mortality. ${ }^{20}$

Individual socio-economic conditions and place of residence determine the survival probabilities too. In urban centres, people would die more and very young, but there were differences between social groups. Lisbon and Porto's quarters enjoyed very different sanitary conditions. The noble areas would be occupied by the richest, whose diet and health would be better. In such quarters, the conditions to isolate and treat people affected by contagious diseases would be more adequate. As cities grew, the relation between immigration, poverty and mortality became closer, while the main epidemic diseases started to affect mainly the poor quarters, where the poor environmental conditions predominated. In rural areas, social differences were less apparent, and inequalities more likely to be due to differences in staple diets or exposure to environmental inclemency. ${ }^{21}$

Death would follow cyclic patterns. Each year, certain repeated circumstances would kill people belonging to certain age and social groups, usually in the same months as the year before. In rural areas, there were always two critical periods. The first one occurred during the winter, when cold and food shortage contributed to the rise of bronco-pulmonary infections. The second one went from July to September when victims were the younger. However, disease and the high prices of food spread the sudden rise of mortality rates at all ages. In urban centres, the relation between men and the environment was more complex. A great number of aspects contributed to change death's trends. The smaller proportion of children, as compared with the total number of inhabitants, was enough to diminish seasonal variations in death rates.

In 1800, the crude mortality rate (henceforth CMR) was higher in the south and in the interior regions of the country, although the higher fertility rates in these areas would make up for this disadvantage. ${ }^{22}$ But internal differences diminished as

20 Those responsible for the report on Lisbon's yellow fever epidemic published in 1857 takes up this question. The report confirms that the most amazing fact was the death of some relevant persons of political, social and artistic scenes. (Teresa Rodrigues, "O quotidiano da morte no Portugal Moderno (séculos XVI-XVIII)", conference held in Lisbon in 1996, at the Universidade Lusófona).

21 Cf. Jorge Crespo, A História do Corpo, Difel, (Lisboa, 1990).

22 Fernando de Sousa, A população portuguesa nos inícios do século XIX. Dissertação de Doutoramento. Faculdade de Letras da UP, (Porto, 1979), 356. 
the century progressed. At the beginning of the $20^{\text {th }}$ century, such differences were of no consequence. What we cannot forget is that, until the end of the Second World War, infant mortality rates underwent cyclic fluctuations, due to the evil effects of some well-known contagious diseases that affected Portugal for much longer than any other European country.

It is impossible to ascertain the exact moment or place in which the decline of crude mortality rates took place for the first time, although it must have happened around the 1890s (table 3 in appendix). At the beginning of the $20^{\text {th }}$ century, rates were moderate and stable, in spite of some conjuncture oscillations. ${ }^{23}$ The decline was progressive, anticipating the fall in fertility rates, a fact that partly explains the positive population growth rates during the following decades. At first, the negative trend evolved slowly, and then it faster, leading to a substantial growth in life expectancy at birth. This last indicator increased from 38 years to 58 years between 1920 and 1950. The most relevant periods were already seen during the 1920s, and later, during the 1940s, in spite of the Second World War. From 1950 onwards, the crude mortality rate continued to fall and the advantages were significant, although the general process became progressively slower, as it approached the highest levels possible within an accelerated ageing structure. During the second half of the century, it raised from 58 to 77 years of age (table 4 in appendix).

The general advances towards survival in the case of Portuguese population are directly connected with the general rise of children's survival probabilities during the last hundred years. By 1900, approximately half of the children died before reaching the age of 15 and infant mortality rates hit 200\%, remaining very high up to the 1940s. Only by the middle of the century did mortality rates fall below $100 \%$, with a delay of 40 or 50 years in relation to more developed countries. The decline was significant after 1960, decreasing a 94\% between then and 2001. 2001 shows the lowest rates of infant mortality, with only 5 cases of death as against 1000 births. The relative contribution of infant mortality to crude mortality rates changed during the last century. Around 1900, it represented $25.1 \%$ of total death rates; in 1995, no it just represented $0.8 \% .{ }^{24}$ Most of this decline can be explained by massive decrease in infectious diseases (table 5 in appendix).

As to children, the most lethal diseases were epidemics: smallpox, scarlet fever, whooping cough and measles, in particular. In some other cases, death was due to croups, diptheria, scrofula and cerebral hydrous. After the hazardous first years of life, the most usual death causes were typhoid fever, chest pains and inflammations of various organs, as well as pregnancy in the case of young women. The ageing process increased the danger of dying due to hydropxies, apoplexies, cancers and

23 Among which, reference should be made to the great epidemic crisis of 1918, which is the last proof of the old demographic regime. See Figure 1.

24 Idem, 84. 
various kinds of unspecified inflammations. At the beginning and at the end of life, most death circumstances were linked to complications in the respiratory and nervous systems. By the end of the 1800s, precarious life conditions, economic working structures, public and private lack of hygiene account for the appearance of tuberculosis as a widespread, main death cause in high-density places. ${ }^{25}$

The decline in infant mortality can be attributed to the improvements in general health conditions, which is enhanced by systematic public health policies, which proved to be efficient; but also to changes in the social and economic conditions of Portuguese population that became clear in the last decades of the $20^{\text {th }}$ century. The improvement of life standards for individuals over 70 is a later process, due both to better preservation of good health through economic, social and cultural factors, but also to medical progress in fighting certain pathologies, namely infections. Advances in life expectancy were moderate during the first half of last century, and very sudden in the last thirty years. While in 1900, Portuguese women lived less than 40 years; by the beginning of the $21^{\text {st }}$ century they may live an average of 81 years, while men may live 74 years (table 4 in appendix). As these figures mounted up, the difference between sexes increased. In 1900, Portuguese women lived about three years more than men. In 1950, the advantage was five years and today it reaches seven years, although women from the south and urban women enjoy a smaller advantage. The augment in female average life expectancy is due to male high mortality in all the different age groups.

In the last decades Portugal has faced a process at the level of sanitarian and epidemic transition. This has contributed to reduce the importance of infectious pathologies, such as those affecting the respiratory and digestive systems. However, it has also led to the increase of degenerative pathologies, such as tumours and other problems linked to the circulatory system. The highest figures pertain to vascular failure. In 1960, circulatory system diseases and malignant tumours were responsible for $35 \%$ of all identified death causes, though in 2001, they came to represent $59.8 \%$.

The relative importance of external factors (such as accidents, poisoning and injury) has increased (table 6 in appendix). ${ }^{26}$ Road accidents deserve to be

25 In Porto, by 1900 and 1901, 17\% of the deaths were attributed to tuberculosis, and this figure did not diminish until the end of the Second World War (João José Maduro Maia, "Padrões de mortalidade e transição sanitária no Porto", População e Sociedade, 1, (Porto, 1995), 237).

26 Maria da Graça Morais, A transição da mortalidade e estruturas de causas de morte em Portugal continental durante o século XX, Dissertação de Doutoramento em Sociologia, Universidade de Évora , I, (Évora, 1999), 263-300. 
mentioned within this category, since they are responsible for one sixth of the deaths among men every year, which affect, specifically, men between 20 and $44 .{ }^{27}$

The slow conquest of survival is a result of the improved efficiency of primary medical care and of a wider and more efficient hospital network. It should be noted that the National Health Service (Portuguese Sistema Nacional de Saúde) was implemented between 1970 and 1981, period during which the most significant increase in life expectancy - up to 65 - took place (table 7 in appendix). The central tenets of change at the level of general life standards and health conditions that impact on the epidemic profile of the country and on life expectancy at all ages are connected to aspects of Portugal's recent history. These include the adoption of the democratic system that followed the revolution of 1974, which is linked to decolonisation of African territories and to the European integration (in 1986). ${ }^{28}$

Therefore, we can conclude that, in the last hundred years, Portuguese population's crude mortality rate has unequivocally receded, in spite of regional differences and evolution pace. Still, infant mortality, which is the indicator that is traditionally a more accurate reflection of socio-economic conditions, remains high by European standards. Only by the 1960s was there a significant improvement of these rates. By 1995 they reached their lowest level, very close to northern and western European average. In recent years, statistics have registered a decrease in yearly casualties due to respiratory, infectious and parasitic diseases, accidents, cirrhosis and liver pathologies, although figures continue to be high for European standards.

Another delicate issue is that of the high percentage of deaths that continue to be classified "signs, symptoms and badly defined morbid states". These were the main death cause for the age groups ranging 1 to 4 and 45 to 54, and still occupying the third place in the table of mortality causes, in 2000. The analysis of the epidemic transition process in Portugal has to take into account the importance that infectious and parasitic diseases still have in the country and the inability to identify some of the death causes. Should these became known, would Portuguese mortality patterns be understood differently?

27 Paula Santana, Helena Nogueira, "A esperança de vida em Portugal”, Cadernos de Geografia, 20, (Coimbra, 2001), 11.

28 A study about social and economical variations of mortality, between 1980 and 1990, justifies the decrease of mortality among manual and factory workers during that decade by improving their life standards after the revolution of April 1974. They had better salaries, better working conditions and occupational health care. ( $\mathrm{M}^{\mathrm{a}}$ do Rosário Giraldes, Ana Cristina Ribeiro, "Desiguladades socio-económicas na mortalidade em Portugal, no período 1980/82-1990/92", Documento de Trabalho 3/95, Associação Portuguesa de Economia da Saúde, (Lisboa, 1995). 


\section{Gender Differences in Life Expectancy}

Figure 2. Life expectancy at birth for men and women in Portugal 1890-2001.

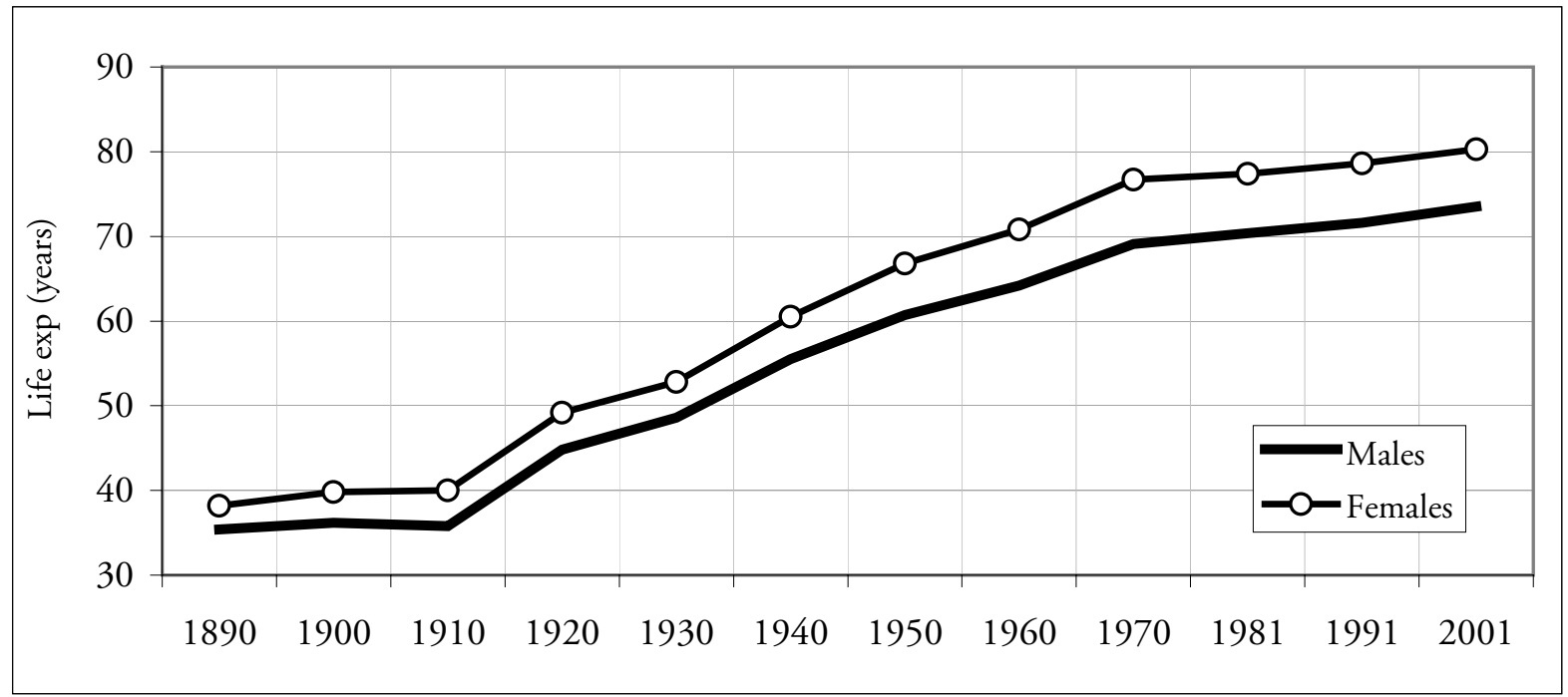

Source: Estatísticas Demográficas, INE, Lisboa, 1890-2001; IVo-XIVo Recenseamentos Gerais da População Portuguesa, INE, Lisboa, 1890-2001.

The Portuguese mortality model fits in the South-European mortality model, despite showing some particularities connected to the country's recent political and social history. One of these relates to the variation of life expectancy between Portuguese men and women, despite the considerable gains of the last three decades. Within the European Union, Portugal has the lowest life expectancy at birth. It is also the EU country whose life span has extended the most in the last 45 years. Between 1950/55 and 1990/95, in Portugal, the increase was of 13,9 years for men and 16,2 for women (figure 2).Between 1970 and 1995, there was an increase rise in the difference of life expectancy between men and women. ${ }^{29}$ Thus, if men who were born in 1970 could expect to live 64.2 years and women 70.8 years, in 1995, those values rose up to 71.6 and 78.6, respectively (table 4 in appendix). These differences between sexes are not exclusive to Portugal and can be explained by the higher mortality rates for men at all ages. Portuguese men die prematurely and lose more years of life due to vehicle accidents, ${ }^{30}$ liver cirrhosis, brain damage, cardio-vascular disease and infectious and parasitic diseases (table 8 in appendix) . HIV/AIDS was the second death cause in the case of men between 25 and 34 and

29 Ana Fernandes, Velhice e Sociedade, Celta Editora, (Lisboa, 1997), 49.

30 Between 1981 and 2000, approximately 78\% of these death causes affectted men (Maria José Carrilho, "Situação demográfica recente em Portugal", Revista de Estudos Demográficos, INE, (Lisboa, 2002), 164.) 
the third for the 35 to 44 year-olds during the $1990 \mathrm{~s},{ }^{31}$ rating among the highest figures in the EU. ${ }^{32}$ If we consider the total amount of 'avoidable' deaths (between 1989 and 1993), i.e. those that happen before 64, for a sample of one hundred and thousand inhabitants, 77.4 women died, as against 170.2 men. $^{33}$

\section{Improvements in Health Services}

An important explanatory factor for the remarkable improvements in life expectancy has been the improved access to good quality health services. The last 30 years have witnessed a sustained effort to improve medical care and the health of the Portuguese. Specific measures included a rise in health care funding, the expansion of health care services - at the level of institutions and at the level of acquisition of new information and medical technologies, wider access to medication and continual efforts to optimise the organization and management of the National Health Service.

During the first half on the $20^{\text {th }}$ century, health care was restricted, fee-paying, and hospital institutions were few and most of them had many deficiencies. After the Second World War, in 1946, a federation of Pensioner's Funds (Portuguese Federação das Caixas de Previdência) was created, offering a complete system of medical and health care to its associate members. In time, other measures followed, which led to the creation of several subsystems, increasing the different access modalities to health care.

By the beginning of the 70 s, during the so-called marcelista spring, ${ }^{34}$ under Marcelo Caetanos' rule and under the motto "health as everyone's right", a network of Medical Centres was proposed. Primary health care in medical centres began in 1971 striving to respond to public health needs: vaccination, antenatal care and childcare, as well as campaigns connected with sanitation and environment. ${ }^{35}$ These services were meant to prevent and give professional support to some groups at risk. This was undoubtedly a big step forward in Portuguese health care assistance, with direct consequences on general demographic mortality indicators.

31 De que se morre mais em Portugal. As principais causas de morte em Portugal de 19901990, Observatório Nacional de Saúde, (Lisboa, 2003).

32 Paula Santana, Helena Nogueira , "A esperança de vida em Portugal”, Cadernos de Geografia, 20, (Coimbra, 2001), 10.

33 Paula Santana, “A mortalidade evitável em Portugal Continental, 1989 a 1993”, Revista de Estudos Demográficos, INE, (Lisboa, 2002), 112.

34 "Primavera marcelista" is the political name given to Marcelo Caetano's first years in the government.

35 A. G Branco e Vítor Ramos Branco, "Cuidados de saúde primários em Portugal", Revista Portuguesa de Saúde Pública, (Lisboa, 2001) 
Unfortunately, the implementation of the network system was slow, never achieving more than half of the intended goals. In the field of hospital care and global management, the Misericórdias, private charity institutions, continued to play an important role since they owned all local and regional hospitals, a central hospital, and a few specialized places for the treatment of specific diseases. ${ }^{36}$

Thus, the Portuguese health care system was fragmented. It consisted of state hospitals, Misericórdia hospitals, medical centres, social and medical care centres for subscribers (Portuguese Serviços médico-socias da Previdência), municipal doctors, maternal and infant care support services against tuberculosis, among others. Till the mid-1970s, actions were directed against specific diseases (such as tuberculosis and those that could be prevented through vaccination) among population groups at risk (such as children and mothers).

The Revolution of 1974 propitiated the necessary political conditions for the creation of a thorough Health National System (NHS), ${ }^{37}$ to which all citizens had a right, which was state funded and covered the whole country, and which was enacted as law and included in Portugal's Constitution of 1976. The main implications of this new right to health care was clearly emphasized by the transfer of all the Misericordia hospitals to the public domain, as well as by the integration of all the already existing health sub-systems into the NHS.

The National Health Service Bill (1979) guaranteed the access of all citizens, regardless of their social or economic situation, to medical and health care. A later revision of the constitution in 1989 changed 'free' medical care to 'tendentially free'. The new bill signalled that funding for health care was to be obtained from the government's general budget instead of from social funds. ${ }^{38}$

From 1983 on, a new branch of medical studies was created, that of General Practitioner, and, at the same time, new medical centres were opened as a result of the fusion of several social care institutions with a view to using available resources in a more efficient way. By the mid-1980s, the NHS inability to suitably respond to the increasing demands, and the financial problems that the system was facing, gave rise to the conditions for the development of a prosperous private health care market that would expand very quickly during the following years. However, universal access to health care, supposedly free of charge, was still guaranteed to all

36 Paula Cristina Almeida Remoalda, A morbilidade e a mortalidade infntil em territórios. Amostra do distrito de Braga - desigualdades territoriais e sociais, Tese de Doutoramento na Universidade do Minho, (Braga, 1998), 98

37 The phases of implementation and expansion of the Health System in Portugal were the following: before 1970, from the beginning of the 70 s to 1985 - implementation and expansion of the health care system -, from 1985 to 1995 - rationalization and assignment of new roles to the private sector - and from 1995 to 2002 - a new public management for the Health system.

38 Observatório Português dos Sistemas de Saúde (OPSS), www.observaport.org 
Portuguese citizens. The hospital network system expanded through the whole of the national territory and several new hospital institutions were built in order to guarantee reasonable access to all people.

However, the well-meant reforms were frequently left incomplete due to management problems, resistance to change or policy discontinuity. Throughout this period, substantial changes took place, even though the same political party and the same Prime Minister continued in charge. Despite the huge progress, Portugal still illustrates insufficient and unequal access to health care. ${ }^{39}$

\section{Conclusion}

The national public health system aims to accomplish two main goals or challenges, which will end with all internal differences and increase life expectancy. As to the first goal, public health policies have to keep geographic diversity in mind, taking into account factors such as place of residence and distance from the health care institutions or specialized personnel. Social and/or economical differentiation is another aspect to consider, as it involves better and quicker treatment as well the economic capability to search for better assistance abroad. The goal must be to guarantee equal access to health care, the increasing efficiency of the sanitary system as well as uniform information levels, based on more active preventive attitudes, premature deceases, healthier life habits (towards consumption of alcohol, smoking, and physical activity) and healthier staple diets (mainly at the informative level, telling people what is best to keep in good health and what should be avoided, changing their mentality).

The second goal is to increase the life expectancy of the whole of Portuguese population. Three aspects should be taken into account to achieve it. The first is related to biological boundaries, i.e. the maximum age up to which we can expect to live with quality; the second is linked to the reduction of endogenous causes of persisting diseases and death. The third seeks to guarantee life quality among the elderly. All this requires adequate equipment strategies: health centres, schools/ professional schools, and pensioners' homes/home assistance. It also requires the existence of groups with specialized qualification in this area, such as physiotherapists, professional instructors, educators for children with special needs and geriatric specialists. Flexibility between the labour market and the social security system is still the hottest point of discussion between government, unions and employers (superannuation, proposing new age limits to stop active life, and a

39 Miguel Pereira, M., J, Bugalho, "Economia da Saúde: novos modelos", Análise Social, 166, XXXVIII, (Lisboa, 2003). 
second professional life, which implies the reinforcement of new strategies (occupations related to community support activities: taking care of children or gardens, transmitting the cultural heritage).

Teresa Veiga is Professor at the Department of Political Studies, Universidade Nova de Lisboa, 1069-051, Lisboa, Portugal. Ana Fernandes is Professor at the Department of Sociology at Universidade Nova de Lisboa, 1069-051, Lisboa, Portugal. Maria João Moreira is Senior Lecturer at the Department of Social Sciences, Instituto Politécnico de Castelo Branco, 6000-084 Castelo Branco, Portugal. 


\section{References}

Baganha, Maria Ioannis, "A emigração atlântica e as migrações internas em

Portugal”, Los 98 Ibericos y el Mar, IV, (Lisboa, 1998), 215-228.

Baganha, Maria Ioannis, "Emigração", Dicionário de História do Estado Novo, I, Círculo de Leitores, (Lisboa, 1996), 294-297.

Branco, António Gomes, Ramos, Vítor, "Cuidados de saúde primários em Portugal”, Revista Portuguesa de Saúde Pública, (Lisboa, 2001).

Crespo, Jorge, A Economia do Corpo em Portugal nos finais do Antigo Regime, UTL, (Lisboa, 1984).

Crespo, Jorge, A História do Corpo, Difel, (Lisboa, 1990).

De que se morre mais em Portugal. As principais causas de morte em Portugal de 1990-1990, Observatório Nacional de Saúde, (Lisboa, 2003).

Carrilho, Maria José, "Evolução Demográfica no período intercensitário 19912001”, Seminário Censos 2001 - Resultados Definitivos, INE, (Lisboa, 2002).

Carrilho, Maria José, "Situação demográfica recente em Portugal", Revista de Estudos Demográficos, INE, (Lisboa, 2002), 147-184.

Desesquelles, Aline, "Le vieillissement démographique dans les pays dévéloppés, Actes des léres Rencontres Sauvy, INED (www.ined.fr).

Fernandes, Ana Alexandre, Velhice e Sociedade, Celta Editora, (Lisboa, 1997).

Fernandes, Ana Alexandre,"Envelhecimento demográfico e transformações da modernidade", Cidade Solidária, Revista da Santa Casa da Misericórdia, 3, (Lisboa, 1999).

Fernandes, Ana Alexandre, "População Mundial, Globalização e Modernidade: Digressão e confronto de sistemas demográficos", Fórum Sociológico, 1/2, (Lisboa, 1999).

Fernandes, Ana Alexandre, "Velhice, Solidariedades Familiares e Política Social. Breve itinerário de pesquisa em torno das consequências do aumento da esperança de vida”, Sociologia, Problemas e Práticas, 36, (Lisboa, 2001).

Giraldes, Maria do Rosário, Ana Cristina Ribeiro, "Desiguladades socio-económicas na mortalidade em Portugal, no período 1980/82-1990/92", Documento de Trabalho 3/95, Associação Portuguesa de Economia da Saúde, (Lisboa, 1995).

Gomes, Maria Cristina Sousa, Prospectiva do Envelhecimento Demográfico na Região de Viseu. O caso particular dos equipamentos sociais para idosos, Dissertação de Doutoramento em Sociologia, FCSH-UNL, (Lisboa, 2000).

Maia João José Maduro,"Padrôes de mortalidade e transição sanitaria no Porto (1880-1929), População e Sociedade, 1, (Porto, 1995), 233-244.

Moreira, Maria João Guardado, A Dinâmica demográfica na regiāo do INTERREG 
Ibérico no Final do Século XX, Dissertação de Doutoramento em Sociologia, FCSH-UNL, (Lisboa, 2001).

Moreira, Maria João Guardado, "A Beira Interior no contexto da fronteira lusoespanhola”, População e Sociedade, 4, (Porto, 1998), 107-122.

Morais, Maria da Graça, A transição da mortalidade e estruturas de causas de morte em Portugal continental durante o século XX, Dissertação de Doutoramentoem Demografia, Universidade de Évora, (Évora, 1999).

Nazareth, J.Manuel, Portugal. Os próximos 20 anos, III - Unidade e diversidade da demografia portuguesa no final do século XX, (Lisboa, 1988).

Nazareth, J.Manuel, “A demografia portuguesa do século XX: principais linhas de evolução e transformação", Análise Social, XXI (87-88-89), (Lisboa, 1985), 963-980.

Nazareth, J.Manuel,"A situação demográfica portuguesa no contexto da União Europeia no início dos anos noventa”, População e Sociedade, 1, (Porto, 1995), 9-26.

Nazareth, J.Manuel, “Conjuntura demográfica da população portuguesa no período de 1970-80: aspectos globais”, Análise Social, XX (81-82), (Lisboa, 1984), 237-262.

Nazareth, J.Manuel, “Prospectiva do Envelhecimento Demográfico na Uniāo Europeia”, População e Sociedade, 2, (Porto, 1996), 77-96.

Observatório Português dos Sistemas de Saúde (OPSS), www.observaport.org

Observatório Nacional de Saúde (ONSA), INE, Esperança de vida sem incapacidade fisica de longa duração, (Lisboa, 2000), (www.ine.pt)

Peixoto, João,"A Emigração Portuguesa a partir de 1980: Factos estatísticos e modalidades de evolução”, Estudos Demográficos, 31, (Lisboa, 1996), 35-74.

Pereira, Miguel, J, Bugalho, M., "Economia da Saúde: novos modelos”, Análise Social, 166, XXXVIII, (Lisboa, 2003).

Remoaldo, Paula Cristina Almeida, A morbilidade e a mortalidade infantil em territórios. Amostra do distrito de Braga - desigualdades territoriais e sociais, Dissertação de Doutoramento na Universidade do Minho, (Braga, 1998).

Rocha Pinto, Maria Luís e Teresa Rodrigues, "1981-1991: As tendências recentes da evolução populacional portuguesa”, História, Ano XVIII (Nova Série), 26, (Lisboa, 1996), 44-53.

Rocha Pinto, Maria Luís e Teresa Rodrigues, "Migrações internas", Dicionário de História do Estado Novo, II, Círculo de Leitores, (Lisboa, 1996), 561-565.

Rocha Pinto, Maria Luís e Teresa Rodrigues, "Natalidade e Fecundidade", Dicionário de História do Estado Novo, II, Círculo de Leitores, (Lisboa, 1996), 657-658.

Rocha Pinto, Maria Luís e Teresa Rodrigues, "Migrações no Portugal do século XX”, Ler História, 43, (Lisboa, 2002), 179-202.

Rocha Pinto, Maria Luís, "As tendências demográficas", Portugal - 20 Anos de 
Democracia, Círculo de Leitores, (Lisboa, 1994), 296-306.

Rodrigues, Teresa, Crises de Mortalidade em Lisboa. Séculos XVI e XVII, Livros Horizonte, (Lisboa 1991).

Rodrigues, Teresa, "A demografia em Espanha e Portugal. Portugal nos dois últimos séculos: as assimetrias de crescimento regional, Los 98 Ibericos y el Mar, IV, (Lisboa, 1998), 139-162.

Rodrigues, Teresa, "As grandes linhas de evolução da população portuguesa no último século”, Seminário Censos 2001, INE, (Lisboa, 2001), 26-35.

Rodrigues, Teresa, "Os factores de mudança no Portugal das regiōes (séculos XIX e XX)", População e Sociedade, 7, (Porto, 2001), 173-193.

Rodrigues, Teresa, Lisboa no século XIX. Dinâmica populacional e Crises de Mortalidade.Dissertação de Doutoramento em História Económica e Social, FCSH-UNL, (Lisboa, 1993).

Rodrigues, Teresa, "A população portuguesa nos séculos XIX e XX: o acentuar das assimetrias de crescimento regional", População e Sociedade, 1, (Porto, 1995), 57-72.

Rodrigues, Teresa, "A população portuguesa no século XX - Permanências e mudanças”, Ler História, 53, (Lisboa, 2003).

Rodrigues, Teresa, "Os portugueses do Século XX: a perspectiva demográfica", História, Ano XVII, 11/12, (Lisboa, 1995), 64-75.

Rodrigues, Teresa, Luís Baptista, "Population and Urban Density: Lisbon in the 19th and 20th centuries", Urban dominance and labour market differentiation of a European capital city, Kluwer Ac.Publ., (London, 1996), 72-122.

Rosa, Maria João Valente, "O envelhecimento da População Portuguesa", Cadernos do Público, 3, Lisboa, (Lisboa, 1996).

Santana, Paula, Helena Nogueira, "A esperança de vida em Portugal", Cadernos de Geografia, 20, (Coimbra, 2001).

Santana, Paula, "A mortalidade evitável em Portugal Continental, 1989 a 1993", Revista de Estudos Demográficos, INE, (Lisboa, 2002), 107-145.

Sousa, Fernando de Sousa, A população portuguesa nos inícios do século XIX Dissertação de Doutoramento. Faculdade de Letras da UP, (Porto, 1979). 


\section{Tables}

Table 1. Phases of differential growth.

\begin{tabular}{cccc}
\hline Inter-census periods* & \multicolumn{2}{c}{ Population } & Annual average growth rate \\
\hline & $\begin{array}{c}\text { Beginning of } \\
\text { period }\end{array}$ & End of period & \\
\hline $\mathbf{1 8 0 1 - 1 8 5 1}$ & 3115330 & 3844119 & 0.42 \\
$\mathbf{1 8 5 1 - 1 9 1 7}$ & 3844119 & 6164018 & 0.72 \\
$\mathbf{1 9 1 7 - 1 9 2 0}$ & 6164018 & 6080135 & -0.46 \\
$\mathbf{1 9 2 0 - 1 9 4 5}$ & 6080135 & 8200913 & 1.20 \\
$\mathbf{1 9 4 5 - 1 9 7 4}$ & 8200913 & 8373508 & 0.07 \\
$\mathbf{1 9 7 4 - 1 9 7 6}$ & 8373508 & 9010160 & 3.73 \\
$\mathbf{1 9 7 6 - 1 9 9 3}$ & 9010160 & 9803869 & 0.50 \\
$\mathbf{1 9 9 3 - 2 0 0 1}$ & 9803869 & 10355824 & 0.69 \\
\hline
\end{tabular}

Source: Io to XIVo Recenseamentos Gerais da População Portuguesa, 1867-2002.

Commentary: 1801-1851 - period of social and political instability, civil war and three French invasions; 1851-1917 - economic (industrial and urban) development, decline in mortality levels; 1917-1920 - critical period (war, emigration, Spanish flu); 1920-1945 - population growth is due to differences between mortality and fertility levels, this last one still high; 1945-1974 emigration stands as the most important variable and influences global population growth; 19741975 - democratic revolution brings 500 thousand people from African colonies and Europe; 1976-1993 - major changes in demographic behaviours; 1993-2001 - Portugal became an positive migratory country.

* Estimated population 1917 = Census population. $1911+$ annual average growth rate.0.78 (1912, $1913)+$ annual average growth rate $0.39(1914,1915,1916)=6164018$.

Est. pop. $1945=$ Census population $1940+1950 / 2+$ correction of null migratory balance $(+68081)=8200913$.

Est. pop. 1974 and 1976 = Census population.1970+ annual average growth rate 1970/81(this procedure leads to an over-evaluation error, due to a lower trend of physiological balances $)+500$ thousand ex-colony inhabitants $=8373$ 508. The decade's median growth rate was levelled in order to obtain the probable population in $1976=9010160$.

Est. pop. 1993 = Census population $1991+$ physiological balances $(1991 / 92)+$ migratory balances $(1991 / 92)=9803869$.

Table 2. Annual natural population growth rate (NR), total population growth rate (TR) and net migration (NM) in Portugal in the $20^{\text {th }}$ century (\%).

\begin{tabular}{cccc}
\hline Inter-census periods & NR & TR & NM \\
\hline $\mathbf{1 9 0 0 - 1 9 1 1}$ & 1.20 & 0.86 & -0.34 \\
$\mathbf{1 9 1 1 - 1 9 2 0}$ & 0.79 & 0.14 & -0.65 \\
$\mathbf{1 9 2 0 - 1 9 3 0}$ & 1.26 & 1.24 & -0.02 \\
$\mathbf{1 9 3 0 - 1 9 4 0}$ & 1.15 & 1.24 & 0.09 \\
$\mathbf{1 9 4 0 - 1 9 5 0}$ & 1.05 & 0.89 & -0.16 \\
$\mathbf{1 9 5 0 - 1 9 6 0}$ & 1.22 & 0.48 & -0.74 \\
$\mathbf{1 9 6 0 - 1 9 7 0}$ & 1.15 & -0.21 & -1.36 \\
$\mathbf{1 9 7 0 - 1 9 8 1}$ & 0.85 & 1.29 & 0.44 \\
$\mathbf{1 9 8 1 - 1 9 9 1}$ & 0.34 & 0.03 & -0.31 \\
$\mathbf{1 9 9 1 - 2 0 0 1}$ & 0.08 & 0.45 & 0.37 \\
\hline
\end{tabular}

Source: Estatísticas Demográficas, 1968, p.LXX e XIo to XIVo Recenseamento Geral da População Portuguesa, 1970,1981,1991 e 2001. 
Table 3. Crude death rates in Portugal in the $19^{\text {th }}$ century (\%o).

\begin{tabular}{cc}
\hline Years & Crude mortality rate \\
\hline $\mathbf{1 8 0 1}$ & 30.3 \\
$\mathbf{1 8 3 8}$ & 20.8 \\
$\mathbf{1 8 4 3}$ & 20.8 \\
$\mathbf{1 8 4 9}$ & 25.0 \\
$\mathbf{1 8 5 0}$ & 22.7 \\
$\mathbf{1 8 6 2}$ & 23.5 \\
1975 & 24.1 \\
1890 & 25.5 \\
1895 & 20.8 \\
1900 & 20.5 \\
\hline
\end{tabular}

Source: IVo Recenseamento Geral da População.

Table 4. Main indicators of mortality levels in the $20^{\text {th }}$ century.

\begin{tabular}{cccccccc}
\hline Years & CMR & IMR & EoM & EoF & AVR(M) & \multicolumn{1}{c}{ AVR(F) } & E0 (M-F) \\
\hline $\mathbf{1 8 9 0}$ & 25.5 & $>200$ & 35.4 & 38.2 & - & - & 2.8 \\
$\mathbf{1 9 0 0}$ & 20.5 & $>200$ & 36.2 & 39.8 & $2.21 \%$ & $4.02 \%$ & 3.6 \\
$\mathbf{1 9 2 0}$ & 23.7 & 161.0 & 35.8 & 40.0 & $-1.12 \%$ & $0.50 \%$ & 4.2 \\
$\mathbf{1 9 3 0}$ & 17.1 & 143.6 & 44.8 & 49.2 & $20.09 \%$ & $18.70 \%$ & 4.4 \\
$\mathbf{1 9 4 0}$ & 15.9 & 126.1 & 48.6 & 52.8 & $7.82 \%$ & $6.82 \%$ & 4.2 \\
$\mathbf{1 9 5 0}$ & 12.2 & 98.0 & 55.5 & 60.5 & $12.43 \%$ & $12.73 \%$ & 5.0 \\
$\mathbf{1 9 6 0}$ & 11.0 & 83.5 & 60.7 & 66.8 & $8.57 \%$ & $9.43 \%$ & 6.1 \\
$\mathbf{1 9 7 0}$ & 10.9 & 51.3 & 64.2 & 70.8 & $5.45 \%$ & $5.65 \%$ & 6.6 \\
$\mathbf{1 9 8 1}$ & 9.7 & 24.3 & 69.1 & 76.7 & $7.09 \%$ & $7.69 \%$ & 7.6 \\
$\mathbf{1 9 9 1}$ & 10.6 & 10.8 & 70.4 & 77.4 & $1.85 \%$ & $0.90 \%$ & 7.0 \\
$\mathbf{1 9 9 5}$ & 10.8 & 6.9 & 71.6 & 78.6 & $1.68 \%$ & $1.53 \%$ & 7.0 \\
$\mathbf{2 0 0 1}$ & 10.2 & 5.0 & 73.5 & 80.3 & $2.59 \%$ & $2.12 \%$ & 6.8 \\
$\mathbf{2 0 0 2}$ & 10.2 & 4.9 & 73.7 & 80.6 & $0.27 \%$ & $0.37 \%$ & 6.9 \\
\hline
\end{tabular}

Source: IIIo a XIVo Recenseamentos Gerais da População Portuguesa, 1893-2002; Estatísticas Demográficas, 1891-2002.

Commentary: CMR (crude mortality rate): deaths/1000 pop; IMR (infant mortality rate): deaths at 0 years/1000 births; EoM and EoF (expectancy at birth for Male and Female): number of years; $A V R(M)$ and $A V R(F)$ (variations between periods for Male and Female): EoM (1890-1900)/100 and $E o F(1890-1900) / 100 ; E o(M-F)$ (differences in life expectancy at birth between Male and Female): number of years.

Table 5. Infant mortality rate (\%o).

\begin{tabular}{ccc}
\hline Years & Endogenous IMR & Exogenous IMR \\
\hline $1960 / 61$ & 15.7 & 67.5 \\
$1970 / 71$ & 17.1 & 36.6 \\
$1980 / 81$ & 13.1 & 10.0 \\
$1990 / 91$ & 6.1 & 4.8 \\
$2000 / 01$ & 2.7 & 2.6 \\
\hline
\end{tabular}

Source: Anuários Demográficos $(1960,1961)$ and Estatísticas Demográficas (1970 to 2002).

Commentary: Exogenous $I M R=$ death caused by infectious diseases and external causes; Endogenous $I M R=$ death caused by non-communicable diseases and physical problems in the first 27 days of life. 
Table 6. Main Death Causes (\%) in Portugal 1930-2000.

\begin{tabular}{lcccc}
\hline \multicolumn{1}{c}{ Causes of death } & $\mathbf{1 9 3 0}$ & $\mathbf{1 9 5 0}$ & $\mathbf{1 9 9 0}$ & $\mathbf{2 0 0 0}$ \\
\hline Circulatory system & 15.5 & 21.9 & 44.2 & 38.9 \\
Tumours & 2.7 & 4.9 & 18.0 & 20.9 \\
Respiratory system & 9.4 & 15.9 & 7.2 & 9.8 \\
External causes & 2.4 & 2.7 & 6.5 & 5.4 \\
Digestive system & 14.2 & 9.2 & 4.5 & 3.9 \\
Endocrinal and metabolic dis. & 0.0 & 0.0 & 3.1 & 4.5 \\
Infectious diseases/AIDS & 23.6 & 18.8 & 0.9 & 2.7 \\
Non specified in official & 32.2 & 26.6 & 15.6 & 13.9 \\
statistics & & & & \\
\hline
\end{tabular}

Source: Maria da Graça Morais, A transição da mortalidade e estruturas de causas de morte em Portugal continental durante o século $X X$, Dissertação de Doutoramentoem Demografia, Universidade de Évora , Évora, 1999; António Barreto (org.) A situação social em Portuga, 19601995, Lisboa, ICS, 1996; Elementos Estatísticos Informação Geral. Saúde/2003, Lisboa, DirecçãoGeral de Saúde, 2003

Table 7. Life Expectancy at 65, for men and women in Portugal 1930-2001.

\begin{tabular}{cccccc}
\hline Years & Males & Females & Differences & AVR(M)\% & AVR(F)\% \\
\hline $\mathbf{1 9 3 0}$ & 11.47 & 13.09 & 1.62 & - & - \\
$\mathbf{1 9 5 0}$ & 12.35 & 14.35 & 2.00 & 0.384 & 0.481 \\
$\mathbf{1 9 7 0}$ & 12.20 & 14.65 & 2.45 & -0.061 & 0.105 \\
$\mathbf{1 9 8 1}$ & 14.36 & 17.95 & 3.60 & 1.762 & 2.253 \\
$\mathbf{1 9 9 1}$ & 14.83 & 18.39 & 3.56 & 0.334 & 0.245 \\
$\mathbf{2 0 0 1}$ & 15.55 & 19.01 & 3.46 & 0.485 & 0.337
\end{tabular}

Commentary: $A V R(M)$ and $A V R(F)=$ variations between periods for Male and Female: EoM (1930-1950)/100 and $\operatorname{EoF}(1930-1950) / 100$. 
Table 8. Loss of years of life, by sex and specific causes of death, in Portugal (per 100,000).

\begin{tabular}{lcccccc}
\hline \multirow{2}{*}{ Causes of Death } & \multicolumn{2}{c}{1990} & \multicolumn{2}{c}{1995} & \multicolumn{2}{c}{2000} \\
\cline { 2 - 6 } & Males & Females & Males & Females & Males & Females \\
\hline All causes & 9143 & 4436 & 8397 & 3692 & 7072 & 3141 \\
$\begin{array}{lcccccc}\text { Tumours } \\
1250\end{array}$ & 953 & 1203 & 872 & 1191 & 824 \\
$\begin{array}{l}\text { Endocrine and } \\
\text { metabolic diseases }\end{array}$ & 222 & 112 & 655 & 196 & 547 & 187 \\
$\begin{array}{l}\text { Diseases of the } \\
\text { circulatory system }\end{array}$ & 1182 & 553 & 1028 & 442 & 855 & 366 \\
$\begin{array}{l}\text { Diseases of the } \\
\text { digestive system }\end{array}$ & 518 & 189 & 460 & 156 & 363 & 134 \\
$\begin{array}{l}\text { Diseases of the } \\
\text { respiratory system }\end{array}$ & 407 & 206 & 306 & 113 & 252 & 104 \\
$\begin{array}{l}\text { HIV/AIDS } \\
\text { External Causes }\end{array}$ & 2774 & 779 & 2280 & 628 & 1560 & 390 \\
$\begin{array}{l}\text { Road accidents } \\
\text { Suicide }\end{array}$ & 1390 & 340 & 1210 & 309 & 654 & 141 \\
\hline
\end{tabular}

Source: Elementos Estatísticos Informação Geral. Saúde/2003, Lisboa, Direcção-Geral de Saúde, 2003.

Commentary: Loss of years is used as an indicator that tries to estimate how many years in total life expectancy are lost by all Portuguese population due to the impact of these specific diseases. 